\title{
INFRARED THERMOGRAPHY AT THE ITC; The Radication Lows
}

\author{
by Masakazu Aoki
}

\section{1. はじめに}

過去10年間, 地球科学の分野に颃いて近赤外線映像 の解析研究がある程度の成果をもって修められてき た。がしかし, 中間・遠赤外線走査データーを用いて物 体の放出熱を知ろらとする熱探査 ${ }^{* 1}$ (Thermography) に関しては決定的な見るべきものはなかった。その理 由として，物体の放射率 (emissiity emittance) を確 実に得られないこと，どらしてもさけられない大気の 影響などがあげられる。さらに, 赤外線走査によって得 られたデーターを解析する技術者が自然物体の流動的 な温度変化を十分に認識していなかったり，又基本的 な物理法則や赤外線（infrared radiation）を放出する 物体の特性を理解していない場合なども考えられる。

このような中で，測定装置の発達には見るべきもの がある。2 バンドの赤外線走查 (infrared line scanners IRLS) は一般に広く用いられ，NASA に拈い ては 8 チャンネルのマルチ・スペクトル装置が実用化 されている。

そこで昨年，マルチ・スペクトル熱探查 (multispectral thermography $\cdots \cdot$...MST) 技術の可能性や, MST のデーター処理実用化を問らために ITC の物 理研究室でパイロット・プロジェクトが設立され, MST の研究及びデーター処理の技術開発に専心する 価値があると結論づけられ，この 1 年間, それらの研 究が進められてきた。当初これに関するドキュメンテ ーションが行なわれた時, MST に打けるまとまった レポートを，ほとんど得ることが出来なかった。又最 近の ESRO (European Space Research Organization）における出版物 “Multi Spectral Sensing”に

\footnotetext{
*1 従来, 熱映像と言われてきたが，地上の物体から放出 される放射量を検知し，それを記録する場合，映像とデジ タルとの両方の記録の仕方があるため,「熱映像」は完全 に満足した用語とは言えない。ここでは Thermography に対する用語として熱探査を用いる。
}

*アジア航測

「写真測量とリモートセンシング」Vol. 14 No. 2, 1975

* Head Physics Section of ITC
颃いても詳しくは述べられていない。そこで ITC の この 1 年間, 研究されてきた最初の課題 MST に関す る物理的基本をできるだけ早くこれらに携わる人々に 紹介することを必要と考え，ここに報告する。

\section{MST に関する実状}

リモート・センシングのすぐれた専門畫において， 物体の熱データーを得るための中間・遠赤外に関する 項目が，重要な部分をしめている。がしかし各国の現 状を見た場合，これらの調査はまだまだ確立された分 野とは，なって扣らず，それは電磁スペクトル (electro magnetic spectrum) に拉ける反射領域を用いた 調査や, サイド・ルッキングレダー（side looking radar）を用いた分野と比較した場合，まだまだそし いものがある。そして, リモート・センシングの中で も, 複雑な分野であるかもしれない。しかし現在, あ る新しい機械によって徐々に，この分野のさまざまな 問題を解決していくことが必要である。それには，ま ず物体の赤外線領域中の熱放出 (infrared heat emission）に関する物理的基本法則を考えなくてはならな い。そして目的物の放射量 (radiant exitant) を知る ために，数多くの経験によってそれぞれの表面温度 (surface temperature), 放射率のデーターを集積して いかなくてはならない。

一方, 物体の熱データーを得るために, 又物体の特 性をつかむために, 中間赤外又は遠赤外の何れを利用 すべきか，あるいは同時に利用すべきだといった効果 が問われている。最近の Kaminsky ${ }^{1)}$ のレポートの中 で, 中間赤外 $(3 \sim 4 \mu \mathrm{m})$ と遠赤外 $(10 \sim 12 \mu \mathrm{m})$ 範囲 の衛星映像写真(infrared satellite picture)を用いて, それぞれのバンドの比較がなされている。彼は十分に 各映像写真を評価した上で, 結論として地球上の自然 物体の温度を測定するのに, 遠赤外よりも中間赤外の 方が効果あることを言っている。がしかし，このレポ ートでは理論的な説明がなされていない。又 ITC で 開かれた ESRO 主催の会議においても, マルチにお けるいくつかのバンドを走査させることの意味が論議 
されている。実際の例として，造岩鉱物の $8 \sim 9.8 \mu \mathrm{m}$ 内の放射率は，それが含有するシリケートの量によっ て，排よそのことがわかっている。このことから $8 \sim 9.8 \mu \mathrm{m}$ の領域と $10 \sim 12 \mu \mathrm{m}$ の領域の放射強度 (radiance intensity) を同時に測定し，それから得ら れる放射率の比をとることにより，シリケートの量を 知らうとする方法がある2。

ここで強調して怙きたいことは, 中間・遠赤外領域 に沶いて，単に物体の熱量を知ることだけではなく， 放射率の差等によって現われてくるさまざまな特性を 解析し，それによって得られる物体の特性をる分類し ていくことを可能としていかなくてはならな。

1900年代に和いて，目的物の温度と，それから放出 されるスペクトルごとの放射物（radiation）の関係が プランクスの法則了) (Plank's law) によってわかって いた。そして，このプランクスの法則は，赤外線走査 による熱探査 (IRLST) を論ずる場合，もっとも基本 をなするのである。このレポートは物理学に不断接し ていない人々がこれに関する法則を利用する場合，最 も理解しやすいように試みた。

\section{3. 放射の法則}

(a) 物体からの熱放射 (heat radiation) とプラン クスの法則

絶対温度 $T[K]^{* 2}$ が $T>0$ であるすべての物体は 長電波 (long radiowaves) 飞始まって赤外線, 可視 光線,さらに柴外線といった，たいへん広い波長带か ら電磁放射 (electromagnetic radiation) を放出して いる。単位時間当りに物体の表面から均等に散乱して いく放射束 (radiant flux 又は power)をその物体の しめる面積で割ったものとして定義される放射量 $M$

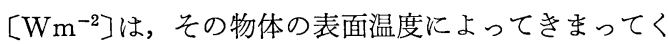
る。そして温度が高ければ高い汪ど放射量は大きく, 又最大スペクトル放射領域は温度が高くなるにつれて 波長の短い方へと移っていく。このことは，むしある 低温状態にある物体を加熱していき，摂氏 $430^{\circ} \mathrm{C}$ （絶 対温度 $700 \mathrm{~K}$ ）にした時，その物体は赤からオレンジ のスペクトル領域で放射量を最大に放出する4)。そし てさらに温度を加えていくと，ダーク・レディシュか らオレンジ色へと，この物体の色は移っていき，もし 6000Kまで上昇出来たとしたならば，我々は，この物 体を白く見ることが出来る。一方, 人間は低温の物体 が赤外線スペクトルで放出しているのを見ることが出

*2 SI (International System of Physical Units) に おける。絶対温度単位は, 以前 degree Kelvin $\left[{ }^{\circ} \mathrm{K}\right]$ で 表わされていたが現在では Kelvin〔K〕で表示されて いる。
来ない。しかし我々の皮膚は放熱物から出る熱を感じ とることが出来，例觉ば風呂場などで $47^{\circ} \mathrm{C}(320 \mathrm{~K})$ の 抒湯の放出熱を感じとることが出来る。

プランクスは，入射した放射物を完全に吸収する物 体，すなわち黒体 (black body) が放出するすべての スペクトルに対しての放射量分布を次のように表わし た。

$$
M_{\lambda}=c_{1} \lambda^{-5}\left[\exp \left(c_{2} \lambda^{-1} T^{-1}\right)-1\right]^{-1} \cdots \cdots(1)
$$

$M_{\lambda}$ ：スペクトル放射量 $\left[\mathrm{Wm}^{-3}\right]$ 又は $\left[\mathrm{Wm}^{-2}\right.$ $\left.\mu \mathrm{m}^{-1}\right]$

$\lambda:$ 波長 $[\mathrm{m}]$ 又は $[\mu \mathrm{m}]$

$T$ : 絶対温度 $[K] 〔 \mathrm{~K}]=$ 摂氏 $273.15^{\circ} \mathrm{C}$

$c_{1}$ : 第 1 定数 $\left(=2 \pi h c^{2}\right) c_{1}=3.741 \times 10^{-16}\left[\mathrm{Wm}^{2}\right]$ 又は $3.741 \times 10^{8}\left[\mathrm{Wm}^{2} \mu \mathrm{m}^{4}\right]$

$c_{2}$ ：第 2 定数 $\left(=h c k^{-1}\right) \quad c_{2}=1.4388 \times 12^{-2}[\mathrm{mK}]$ 又は14.388[ $\mu \mathrm{mK}]$

$h:$ プランクス定数 (Plank's Constant)

$c:$ 光の速度

$k$ : ボルッマン定数 (Boltzmann's Constant)

〜尚, この式から得られるスペクトル放射量は真空 状態，大気中に执いては $M^{\prime}{ }_{\lambda}=M_{\lambda} \cdot n^{2}$ となる $n=$ 1.0003 ( $n$ は空気中の屈折率)

ここでのスペクトル放射量 $M_{\lambda}$ （従来からの呼び 方をするとスペクトル放射発散度……spectral radiant emittance ${ }^{3)}$ ) はすで物体の表面から均 等に散乱していくスペクトル放射束を，その物体 のしめる面で割った值として定義され，電磁放射 のあらゆる偏光モード (polarisation modes) に 対して用いられる。このように放射量の単位は, 物体から放出する放射の状態を見るとき便利なも のであり5.（ステファン・ボルッマンの法則）で 用いる。しかしりモート・センシングにおいては 単位立体角 (per unit solid angle) 内の範囲から 放出される放射束が最も重要となる。それは，あ る目的物の放射束をエアーボーンに積まれた装置 から測定する場合，必ずその間に立体角の関係が 出来るからである。そして，この単位として次に 示す 2 種類がある5)。

それは，放射強度 $I$ (radiant intensity)

$\left[\mathrm{Wsr}^{-1}\right]$ スペクトル放射強度

$I_{\lambda}$ (spectral r.i.) $\left[\mathrm{Wsr}^{-1} \mu \mathrm{m}^{-1}\right]$

と放射輝度 $L$ (radiance)

$\left[\mathrm{Wm}^{-2} \mathrm{sr}^{-1}\right]$ スペクトル放射輝度 $L_{\lambda}$ (spectral r.) $\left[\mathrm{Wm}^{-2} \mathrm{sr}^{-1} \mu \mathrm{m}^{-1}\right]$ 
前者は放射源から，ある方向の単位立体角内に出 る放射束として定義される。後者は，ある放射源 の単位面積からある方向の単位立体角内に出てい く放射束である。そして互いに $L=M / \pi=I / A$, $L_{\lambda}=M_{\lambda} / \pi=I_{\lambda} / A$ の関係がある。もし放射源の直 径がその物体と検知器の距離の $5 \%$ を満ないなら 放射輝度の要素となる面は無視することが出来 る。すなわら $L=I$ 又は $L_{\lambda}=I_{\lambda}$ となる。我々は, このレポートでは主にスペクトル放射輝度 $L_{\lambda}$ を 単位とする*3。

*3 次の表で, このレポートに用いられる放射(光)に関す る用語の定義を記しておきたい。
前に述べたように，プランクスの法則で対象となる 物体は完全散乱する理論的に考光出された黒体であり, 又との物体の完全平坦面の法線から 1 ラジアン $\left(50^{\circ}\right.$ 〜 $\left.60^{\circ}\right)$ の範囲でこの放射が成り立つ。

図 1 (次頁) は我々が対象とする温度 $200 \mathrm{~K}$ から $473 \mathrm{~K}$ までの黒体のスペクトル放射輝度をプランクスの法則 によって，それぞれ座標軸を異にして表わしたもので ある(プランスカーブ)。

(b) ビィーンの変位則 (Wien's law)

前項でとりあげた図 1 におけるプランスカーブを見 ると，温度の増加とともに，それぞれの最大值が短い 波長域 (左側) の方へと移動していくのがわかる。そ

放 射

\begin{tabular}{|c|c|c|c|c|c|}
\hline \multicolumn{2}{|c|}{ 用語 } & \multirow{2}{*}{$\begin{array}{l}\text { 記 } \\
\text { 号 } \\
W\end{array}$} & \multicolumn{2}{|c|}{ 単位 } & 意 \\
\hline 放射エネルギー濃度 & $\begin{array}{l}\text { Radiant } \\
\text { Energy } \\
\text { Density }\end{array}$ & & joule/metre ${ }^{3}$ & $\mathrm{Jm}^{-3}$ & 単位体積当りの放射エネルギー $W=d Q / d V$ \\
\hline 放射エネルギ一 & $\begin{array}{l}\text { Radiant } \\
\text { Energy }\end{array}$ & $Q$ & joule & $\mathrm{J}$ & 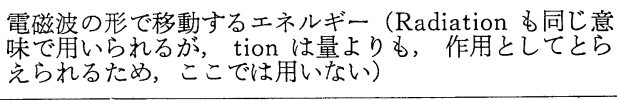 \\
\hline 放 射 束 (力) & $\begin{array}{l}\text { Radiation } \\
\text { Flux } \\
\text { (Power) }\end{array}$ & $\Phi$ & watt & W & 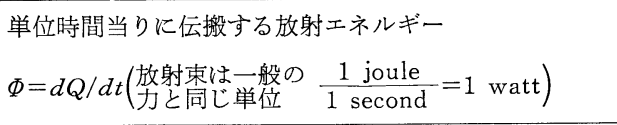 \\
\hline 放 射 強 度 & $\begin{array}{l}\text { Radiant } \\
\text { Intensity }\end{array}$ & I & $\begin{array}{l}\text { watt/ } \\
\text { steradian }\end{array}$ & $\mathrm{Wsr}^{-1}$ & $\begin{array}{l}\text { 点放射源から， ある方向の単位立体角内に出ていく放射 } \\
\text { 束 } I=d Q / d w\end{array}$ \\
\hline 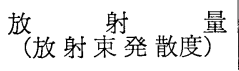 & $\begin{array}{l}\text { Radiant } \\
\text { Exitance }\end{array}$ & $M$ & $\begin{array}{l}\text { watt/ } \\
\text { metre }^{2}\end{array}$ & $\mathrm{Wm}^{-2}$ & 単位面積当りの放射束 $M=d \Phi / d A$ \\
\hline 放 射 照 度 & Irradiance & $L$ & $\begin{array}{r}\text { watt/metre } \\
\cdot \text { stradian }\end{array}$ & $\mathrm{Wm}^{-2} \mathrm{sr}^{-1}$ & $\begin{array}{l}\text { ある放射源の単位面積から， ある方向の単位立体角内に } \\
\text { 出ていく放射束 } L=(d I) / d A \cdot \cos \theta\end{array}$ \\
\hline 放 射 輝 度 & Radiance & $E$ & $\begin{array}{l}\text { watt/ } \\
\text { metre }^{2}\end{array}$ & $\mathrm{Wm}^{-2}$ & 単位面積当りに入射する放射束 $E=d \Phi / d A$ \\
\hline
\end{tabular}

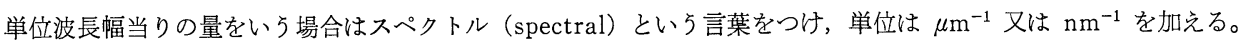

光

可視領域では, watt が lumen に, watt/steradian が candela に変わる。

\begin{tabular}{|c|c|c|c|c|}
\hline 用 & 語 & 記 & 単 & 位 \\
\hline 光エネルギー濃度 & Luminous Energy Density & $W_{v}$ & talbot/metre ${ }^{3}$ & $\operatorname{lm} \cdot \mathrm{m}^{-3}$ \\
\hline 光エネルギー & Luminous Energy & $Q_{v}$ & talbot & \\
\hline 光 束 （力） & Luminous Flux (Power) & $\Phi_{v}$ & lumen & $\operatorname{lm}$ \\
\hline 度 & Luminous Intensity & $I_{v}$ & candela & $\mathrm{cd}$ \\
\hline 光量 (光束発散度6) & Luminous Exitance & $M_{v}$ & lumen $/ \mathrm{metre}^{2}$ & $\mathrm{~lm} \cdot \mathrm{m}^{-2}$ \\
\hline 度 & Luminounce & $L_{v}$ & candela/metre ${ }^{2}$ & $\mathrm{~cd} \cdot \mathrm{m}^{-2}$ \\
\hline 照 & Illuminance & $E_{v}$ & lumen/metre ${ }^{2}$ & $\operatorname{lm} \cdot \mathrm{m}^{-2}$ \\
\hline
\end{tabular}




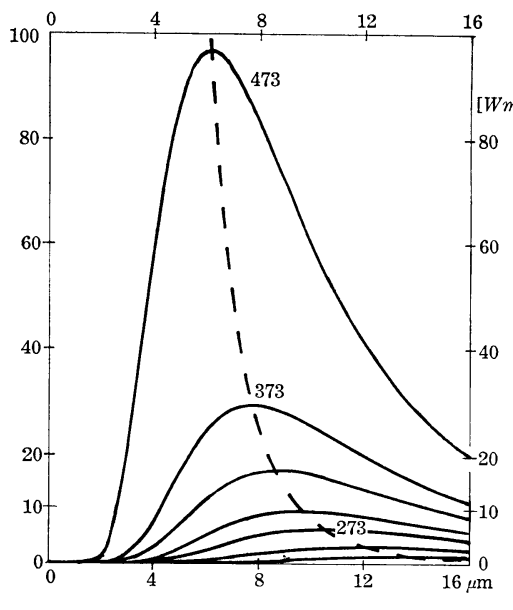

$\lim$

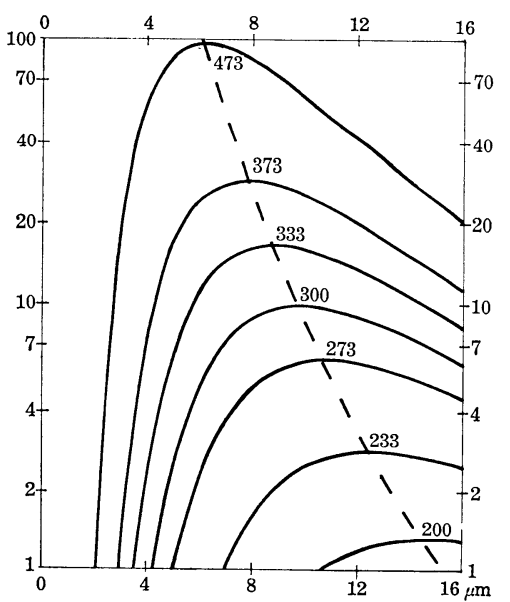

図 1 座標軸を異にしたさまざまな黒体放射カーブ

(放射の単位は $\mathrm{Wm}^{-2} \mathrm{sr}^{-1} \mu \mathrm{m}^{-1}$ 放射輝度)

このグラフでは放射輝度を縦軸に，波長を横軸に温度をパラメータとする。温度は，我 々の調査対象とする $200 \mathrm{~K} \leqq T \leqq 473$ までを表わす。
$\mathrm{a}$ : 縦軸・線形
横軸 ・ 線形
$\mathrm{b}:$ 縦軸
c：" 対数 11 線形
$\mathrm{d}: 1 / \quad$ 対数

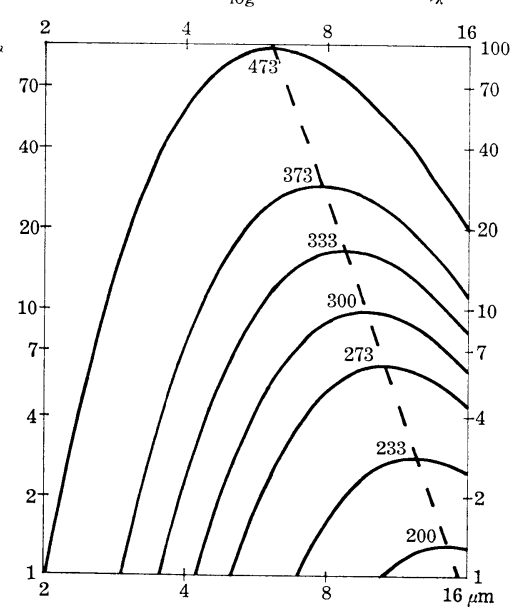

対数点線はビィーンの変位則 $\left(L_{\lambda}=836567 \lambda^{-5}\right)$

して，それぞれの最大值をつないだ曲線（両対数座標 では直線）はプランクスの法則を微分することによっ て次のよう汇表わせる。

$$
\lambda_{\max } \cdot T=2898[\mu \mathrm{mK}]
$$

我々が，ここでこの式を取りあげたのは，黒体の温度 とそのスペクトル放射輝度, さらにその時の波長の関 係が次の上うに容易比計算出来ることからによる。例 兄ぱ, $16.7^{\circ} \mathrm{C}(289.8 \mathrm{~K})$ の物体が最大に放射輝度を放 出する波長 $\left(\lambda_{\max }\right)$ は式(2)から， $\lambda_{\max }=10 \mu \mathrm{m}$ である ことがわかる。そして，この物体を加熱し，3增した 場合，すなわち $1 \%$ 増加したとき，その時の $\lambda_{\max }$ は 同様(2)式より， $\lambda_{\max }=9 \mu \mathrm{m}$ となる。ゆえに，温度を $1 \%$ 増加したとさ，最大放射スペクトルは $1 \mu \mathrm{m}$ 短い 所に移動したことになる。このことから，ある温度の みたい。

(c) プランクスの近似式
物体を，増加させた場合 その増加率の負の值をも との $\lambda_{\max }$ に加兄ること により, 増減後の $\lambda_{\max }$ を得ることが出来る。

ビィーンの変位則から 得た $\lambda_{\max }=2898 / T$ をプ ランクスの法則に代入す ることにより，ある温度 とその時の最大スペクト ル放射輝度の関係式を得 ることが出来る。

$L \lambda_{\max }=4.098 \times 10^{-12}$ $T^{5}\left[\mathrm{Wm}^{-2} \mathrm{sr}^{-1}\right.$ $\left.\mu \mathrm{m}^{-1}\right]$

この函数は入に関しても $L \lambda_{\max }$ を得ることが出来 る。

$$
\begin{gathered}
L \lambda_{\max }=8.366 \times 10^{5} \\
\lambda^{-5}\left[\mathrm{Wm}^{-2} \mathrm{sr}^{-1}\right. \\
\left.\mu \mathrm{m}^{-1}\right] \quad \cdots \cdots(4)
\end{gathered}
$$

我々は(2)，(3)，(4)式をビ 1ーンの変位則と呼ぶ。

図1亿打いても明らか なよらに，温度が $233 \mathrm{~K}$ から $473 \mathrm{~K}$ まで上昇した とき，すなわち 2 倍上昇 した時, 最大スペクトル 放射輝度は2.8から100へ と $100 / 2.8=2^{5}$ 倍上昇し ている。これは(3)式から も理解出来る。今仮に $T$ が $1 \%$ 増加したとき，(3)

式の $L \lambda_{\max } \times T^{-5}$ の関係から $L \lambda_{\max }$ は $5 \%$ 増加する ことになる。このことは逆にもしある検知器が目的物 の $\lambda_{\max }$ と一致する波長領域で，1\%の誤差をもって スペクトル放射輝度を測定した場合, これから得られ る温度は $0.2 \%$ の誤差をもっていることになる。

このことで，ある特別の場合 $\left(\lambda_{\max }\right)$ に理論的な温 度と放射輝度の関係がビィーンの变位則でわかった。 そして次項で数学的な解法をもとに任意の状態に話を 広げてみたい。しかし，その前に，プランクスの法則 をもら少し詳しく述ベ，プランクスの近似式（ビィー ン式，レイライ・ジェン式）の有效性について述べて

黒体に対する熱放出の理論としてプランクスの法則 


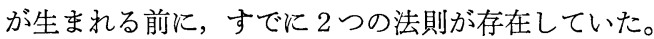
そしてそれらはある波長領域のみに関して応用するこ とが出来る。すなわち短い波長領域に応用されるビィ ーン式 (Wien's descirption)

$$
M_{\lambda}=c_{1} \lambda^{-5} \exp \left(-c_{2} \lambda^{-1} T^{-1}\right)
$$

と長い波長領域で有効となるレイライ・ジェン式 (Rayleigh-Jean's formulation)

$$
M_{\lambda}=2 \pi c k T \lambda^{-1}
$$

である(( 9$) ，(10)$ 式を参照)。

現在，これらは実際の仕事の分野においてプランク スの近似式として用いられている。プランクスの法則 から得られる量を真值とした場合, ビィーン又はレイ ライ・ジェン式に必ず誤差が生ずる。そこで,これらの 䛊差を得るためには数式的にこれらの公式を比較せね ばならない。まずビィーン式に関して見てみると，今 仮にプランクスの法則とビィーン式の両方に共通する $c_{2} \lambda^{-1} T^{-1}$ を

$$
\begin{aligned}
& c_{2} \lambda^{-1} T^{-1}=3 \quad \text { と仮定すると } \\
& \exp \left(c_{2} \lambda^{-1} T^{-1}\right)=20
\end{aligned}
$$

ゆえに プランクスの法則

$$
\begin{aligned}
& \text { ビィーン式 } \\
& \frac{c_{1} \lambda^{-5}\left[\exp \left(c_{2} \lambda^{-1} T^{-1}\right)-1\right]^{-1}}{c_{1} \lambda^{-5} \exp \left(-c_{2} \lambda^{-1} T^{-1}\right)}=\frac{21}{20}
\end{aligned}
$$

となり，打のおのの差は $5 \%$ となる。すなわち

$$
\lambda T=c / 3=14388 / 3=4800
$$

のとき，ビィーン式は $5 \%$ 䛊差を生ずる。同様にし

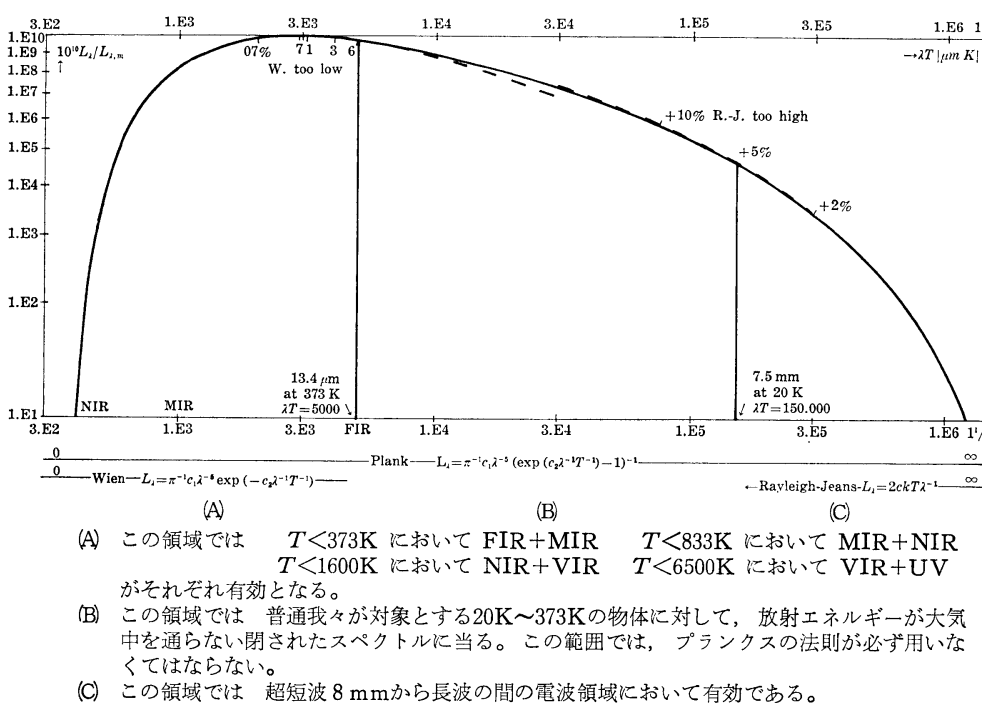

図 $2 \log \left(\log L_{\lambda} / L_{\lambda} \max \right)$ 対 $\log \lambda T$ のグラフ (単位 1 E $10=10^{10}, 2$ E $3=20^{3}$ )

縦軸 $L_{\lambda} / L_{\lambda} \max$ の比を 2 回対数にとり，横軸を $\lambda T$ の対数をとったスペクトル放射グ ラフ。すべての物体が，放射するスペクトル領域を，それぞれの適用し5る法則ごとに 区分，リモート・センシングを実際に応用する場合，ぞの法則が啇用しえるかを容易に 判断出来うるように描いた。ここで問題としなくては，ならないのは，短い波長におい てビインクス近似式が，長い波長に和いてレイライト・ジェン近似式が有効であること である。
て， $\lambda T=4000$ のとき $2.8 \%, \lambda T=3000$ のとき $0.8 \%$ となる。又 $\lambda T=6000$ の時は $10 \%$ と大き誤差を生 じ，ビィーン式をプランクスの近似式として用いられ ない所となる。すなわち， $\lambda T$ が拈拈よそ5,000以上に なるとビィーン式はプランクスの近似式としての役目 を果たさなくなる（参照図 2)

前回で我々は放射輝度の值が最大となる時の $\lambda T$ の 関係はビィーンの変位則 $\left((2)\right.$ 式) として， $\lambda_{\text {max }} \cdot T=$ $2898[\mu \mathrm{mK}]$ を得た。そこでビィーン式から導き出さ れる $\lambda_{\max } \cdot T$ を得，その誤差を見てみる。ビィーン式 (5)を入で微分してみると，

$$
\begin{aligned}
\frac{d L_{\lambda}}{d \lambda} & =-5 \pi^{-1} c_{1} \lambda^{-6} \exp \left(-c_{2} \lambda^{-1} T^{-1}\right)+\pi^{-1} c_{1} \lambda^{-5} \\
& \exp \left(-c_{2} \lambda^{-1} T^{-1}\right) c_{2} \lambda^{-2} T^{-1}=\pi^{-1} c_{1} \lambda^{-7} \exp (- \\
& \left.c_{2} \lambda^{-1} T^{-1}\right)\left(c_{2} T^{-1}-5 \lambda\right) \quad \cdots \cdots(7)
\end{aligned}
$$

となる。そこで $d L_{\lambda} / d \lambda=0$ をとってみると，

$$
5 \lambda_{\max }=c_{2} T^{-1}
$$

ゆえに $\lambda_{\max } T=14388 / 5=2878$ となる。

すなわち，(2)式の $\lambda_{\max } T$ と比較してみると，ビィ一 ン式に0.7\%の誤差が生じていることになる。

次に，レイライ・ジェン式について論じる。プラン クスの法則をテーラ展開すると，

$$
\begin{aligned}
L_{\lambda} & =c_{1} \lambda^{-5}\left[\exp \left(c_{2} \lambda^{-1} T^{-1}\right)-1\right]^{-1} \\
& =c_{1} \lambda^{-5}\left[1+\left(c_{2} \lambda^{-1} T^{-1}\right)-1\right]^{-1}
\end{aligned}
$$

$(\exp x=1+x+1 / 2 \cdot x \cdots \cdots$ の最初の 2 項を用 (る)

$$
\begin{array}{r}
=c_{1} \lambda^{-5}\left[c_{2}{ }^{-1} \lambda T\right] \\
\cdots \cdots(8 \mathrm{~b}) \\
c_{1}=2 \pi h c^{2}, \quad c_{2}=h c k^{-1} \\
\text { より } \\
=2 \pi h c^{2} \cdot h^{-1} c^{-1} k \cdot \lambda^{-4} T \\
=2 \pi c k \lambda^{-4} T
\end{array}
$$

となり，レイライ・ジェ ン式と一致する。そこで レイライ・ジェンと全く 同じ( $8 \mathrm{~b})$ 式とプランク スの法則である(8 a)式 を比較してみる。今仮に $\lambda T=150,000 \mu \mathrm{mK}$ (すな わち $\left.c_{2} \lambda^{-1} T^{-1}=0.095\right)$ とすると $\exp \left(c_{2} \lambda^{-1} T^{-1}\right)$ =1.10となる。これを， それぞれに代入すると，

(8 a) 式は

$$
\begin{aligned}
L_{\lambda} & =c_{1} \lambda^{-5}[1.10-1]^{-1} \\
& =10.0 c_{1} \lambda^{-5}
\end{aligned}
$$

$(8 \mathrm{~b})$ 式は 


$$
L_{\lambda}=c_{1} \lambda^{-5}[1 / 0.095]=10.5 c_{1} \lambda^{-5}
$$

となり， $\lambda T=150,000 \mu \mathrm{mK}$ のとき， $5 \%$ の誤差をも ってレイライ・ジェンから得られる放射輝度の值の方 がプランクスから得られる值よりる大きいことがわか る。同様にして $\lambda T=15,000 \mu \mathrm{mK}$ のとさ $10 \%, \lambda T=$ $300,000 \mu \mathrm{mK}$ のとき $2 \%, \lambda T=1200,000 \mu \mathrm{mK}$ のとき $0.5 \%$ 得ることが出来る (参照 2 図)，ゆえに $\lambda T \leq$ 150,000 の範囲では誤差が $5 \%$ をこ，レイライ・ジェ ン式がプランクスの近似式として適用できないことが わかる。尚, 一番最後の值 $\lambda T=120,000 \mu \mathrm{mK}$ は, 対 象温度が $300 \mathrm{~K}$ のとき $\lambda=4 \mathrm{~mm}$ となり, 乾燥した物 質をよく透過する最も短い波長として重要なものであ る。このようにレイライ・ジェン式は，レーダーのよ らな能動的 (active) リモート・センシングに応用さ れ，精度的にも問題はない。

前回の式に执いて，プランクスの法則の指数部分が 近似的に $\lambda T / c_{2}$ となり, プランクスの法則が $L_{\lambda}=$ $2 \pi c k T \lambda^{-4}$ となることを導いた。これを $\mathrm{SI}^{* 2}$ の単位で 書いてみると，

$$
L_{\lambda}=2 c k T \lambda^{-4}\left[\mathrm{Wm}^{-2} \mathrm{sr}^{-1} \mathrm{~m}^{-1}\right]
$$

( 1 単位面積当りから 1 ステラジアン立体角に散 乱する一定波長領域の放射輝度……ワット...) となる。

しかし，一般に電磁波を取り扱う場合，波長よりも 周波数の単位が用いられる。そこで (9)式を周波数の 単位に変えるため $v=c / \lambda(v$ : 周波数; 放射の伝播速 度を波長で割った単位)を微分してみると，dv=d(c) $\lambda)=-c \lambda^{-2} d \lambda$ となり，これを(9)式に代入して，L $L_{\lambda}$ $=2 k T \lambda^{-2}$ を得る。

$$
L_{v}=2 k T \lambda^{-2}\left[\mathrm{Wm}^{-2} \mathrm{sr}^{-1} \mathrm{~Hz}^{-1}\right]
$$

以上，プランクスの近似式を論ずることにより，我々 が必要としている短い波長，長い波長領域での放射物 をより深く追求していくことが可能となった。

\section{4. 温度変化に対する放射}

(a) 温度と放射

プランクスの法則を図 3 のように両対数で描いてみ ると，それぞれの異なった温度に和ける黒体放射曲線 (black body radiance curve) がずで同じ形を示 す。又それぞれの最大変換点が直線（ビィーンの直線 wien's line: ビィーンの変位則から得られるもの)で 結ばれる。すなわちこの一定の形をした黒体放射曲線 を，ビィーンの直線にそってすべらすことにより，各 温度のスペクトル放射曲線が得られる。そこで, 温度 $300 \mathrm{~K}$ のカーブに着目し，これを $3.3 \%$ 上昇させ $310 \mathrm{~K}$ にし，それぞれの放射輝度の值を比較してみる。スペ クトル $\lambda=11 \mu \mathrm{m}$ に打汀るそれぞれの放射輝度は図 3

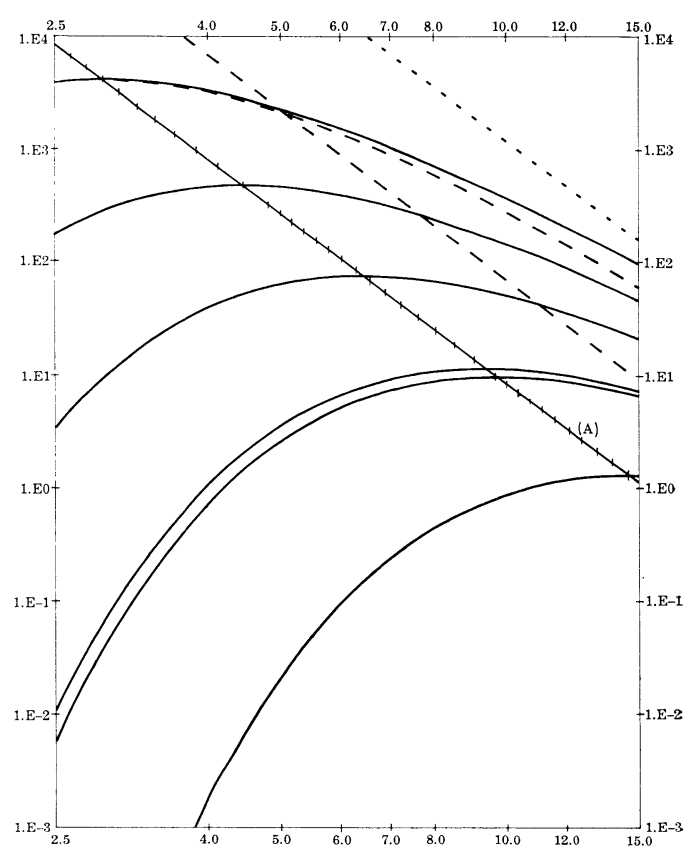

図 3 プランクスの両対数黒体放謝カーブ 中間赤外・遠赤外領域の $200 \mathrm{~K}$ から1,000Kまでの放 射輝度を示す。

より $300 \mathrm{~K} て ゙ 10 \mathrm{~W} ， 310 \mathrm{~K} て ゙ 11.6 \mathrm{~W}$ とり，16\%の上昇 を示したことになる。又 $3.3 \mu \mathrm{m}$ の所では, この $2 つ$ のカーブの差が $\log 1.7$ となり， $70 \%$ 上昇を示して いる ( $\log 10$ は10倍, $\log 1.7$ は1.7倍)。同様にして, $5 \mu \mathrm{m}$ の所ではとの差は $\log 1.4$ となり $40 \%$ の上昇と なる。逆に $310 \mathrm{~K}$ から $300 \mathrm{~K}$ に減少させる場合, $310 \mathrm{~K}$ の時を $100 \%$ と考光， $3.3 \mu \mathrm{m}$ 飞拈ける放射輝度減少率 は，(70/170) $\times 100 \%=41 \%$ となる。又 $350 \mathrm{~K}$ の時の放 射輝度を $100 \%$ としたとき，305Kから $310 \mathrm{~K} へ$ の昇， 又は $300 \mathrm{~K} へ の$ 減少は $\pm(35 / 135) \times 100 \%= \pm 26 \%$ とな る。同様に $5 \mu \mathrm{m}$ の位置に㨟いても，300Kから $310 \mathrm{~K}$ への増加が $40 \%$ であのに対して，310Kから $300 \mathrm{~K} へ$ の減少は(40/140) ×100\%=29\%の減, 又は $305 \mathrm{~K} か ら$ のそれぞれ $5 \mathrm{~K}$ の増減は土16.7\%となる。

このことから，温度增減による放射輝度の変化は, 中間赤外領域の空の方が遠赤外領域の空よりも大きい ことがわかった。すなわらカミンスキーのとりあげた 結論に一致することになる。

ここで少し考えておかなくてはならないことは，温 度 $300 \mathrm{~K}$ 前後の低温物質から放出される中間赤外領域 の絶対的放射量は，遠赤外領域のそれの1/10である。 又ある温度をもった物体が，その $n$ 倍加熱された（又 は $m \% の$ 加熱）とすると，もとの最大放射点に括ける スペクトルと新しい加熱後のそれは $1 / n$ 倍 $(m \%$ の 減)の関係, 最大放射輝度は $n^{5}$ 倍 $(5 \times m \%$ の増)の 
関係にある。

(b) 熱変化に対するスペクトル 放射輝度の比例数

ここで，もら少し温度変化に対 する放射輝度変化を見るために， プランクスの法則を $T$ で微分して みると，

$$
\begin{aligned}
\frac{\partial L_{\lambda} T}{\partial T} & =\pi^{-1} c_{1} \lambda^{-5}\left[\operatorname { e x p } \left(c_{2} \lambda^{-1}\right.\right. \\
& \left.\left.T^{-1}\right)-1\right]^{-2} \exp \left(c_{2} \lambda^{-1}\right. \\
& \left.T^{-1}\right) c_{2} \lambda^{-1} T^{-1} \cdot T^{-1} \\
& =L_{\lambda} c_{2} \lambda^{-1} T^{-2}[1-\exp \\
& \left.\left(-c_{2} \lambda^{-1} T^{-1}\right)\right]^{-1}
\end{aligned}
$$

となる。この式は，温度変化を論 ずる場合, かなり複雑であるため ここでビィーン式をTで微分し，

$$
\frac{\partial L_{\lambda}}{\partial T}=L_{\lambda} \cdot c_{2} \lambda^{-1} T^{-2}
$$

これから

$$
\frac{\partial L_{\lambda}}{L_{\lambda}}=\frac{c_{2}}{\lambda T} \cdot \frac{\partial T}{T} \text { を得, これ }
$$

を用いることにする。

この式は，微量な $\Delta T$ 亿対する $\Delta L_{\lambda}$ の変化は実際の $T$ と $L_{\lambda}$ の比 に一致していることを示してい る。今， $\frac{c_{2}}{\lambda T}=p$ とおくと，

$$
\frac{\partial L_{\lambda}}{L_{\lambda}}=p \cdot \frac{\partial T}{T}
$$

となり, 我々は, $p^{* 4}$ をスペクトル放射輝度の比例数 と名づける。そこで, 一番簡単にスペクトル放射輝度 の比例数を求められるものとして, 最大放射輝度を放 出するスペクトル $\lambda_{\max }$ に対する定数 $p=\frac{c_{2}}{\lambda_{\max } \cdot T}$ を

*4この項では，スペクトル放射輝度 $\left(L_{2}\right)$ 変化を見てい るためにスペクトル放射輝度の比例数と名づける。 次項のステファン・ボルツマンの法則では全スペクト ル領域の放射量を対象とするために，放射量の比例数と 名づける。

○プランクスの法則から得られた $P$ を $P_{p}$ (スペクトル 放射輝度の比例数)

○ビィーン式から得られた $P$ を $P_{\omega}$ （スペクトル放射輝 度の比例数)

○ステファン・ボルツマンの法則, 又はプランクスの法 則を積し，この平均值から得られたPを $\overline{P_{a n}}$ (放射量 の比例数)

○任意のスペクトル領域（例壳ば中間赤外から遠赤外 3. $3 \sim 13 \mu \mathrm{m}$ )を対象とする $P$ を $\overline{P_{a n}}$ (放射量の比例数)

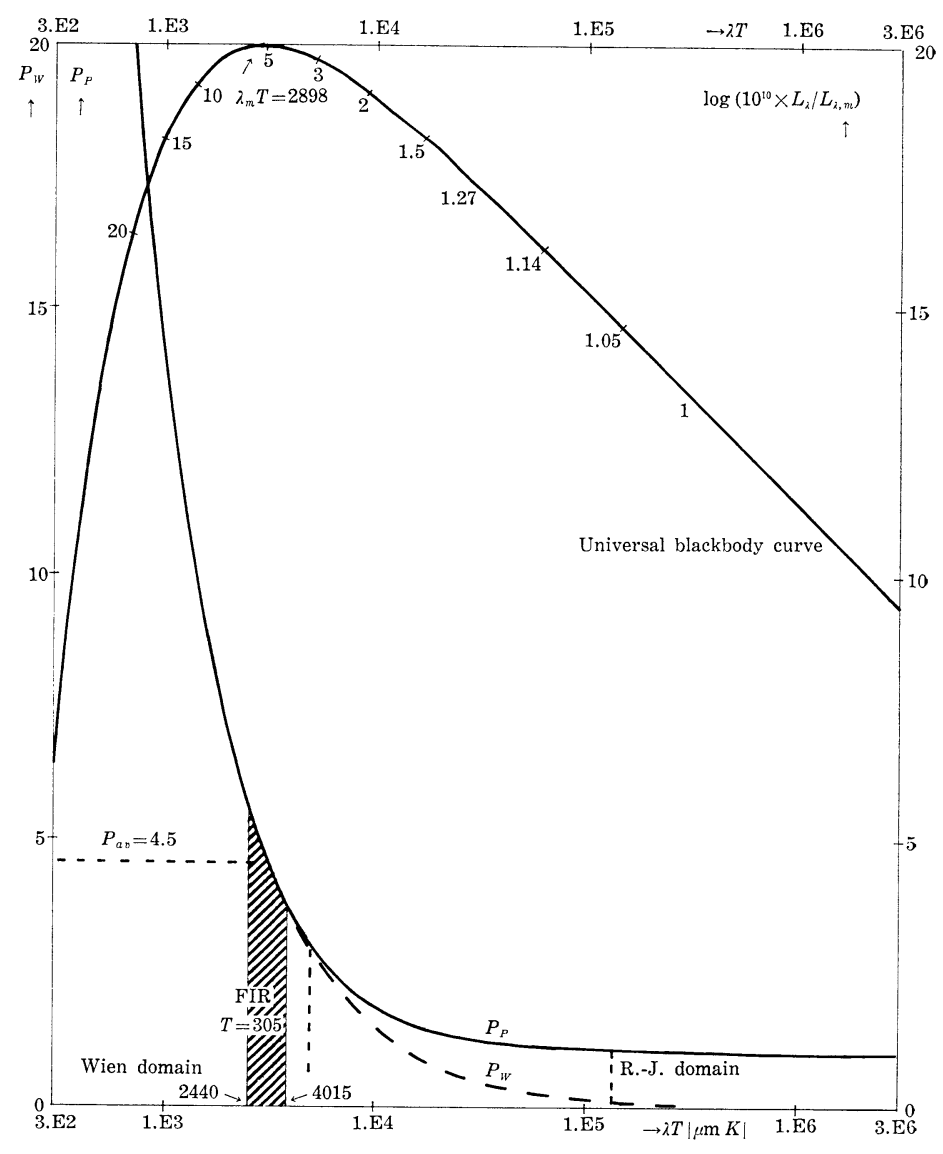

図 4 比例式 $\boldsymbol{p}(=\boldsymbol{T} / \boldsymbol{L}, \partial \boldsymbol{L} / \delta \boldsymbol{T})$ カーブ

約 $\lambda T=3,000=3 \mathrm{E} 3$ あたりからビンクス近似式 $p_{w}$ カーブは, プランクス法 則 $p_{p}$ カーブをそれていく。そして， $p_{p}$ の価は，プランクス黒体放射カーブ $\left(20+\log L \lambda / L_{\lambda} \max \right)$ の上に示した。

計算してみる。(7)式より

$$
\text { (7)式 }=0 \text { のとき } p=\frac{c_{2}}{\lambda_{\max } T}=5
$$

ゆえに， $\frac{\partial L_{\lambda \max }}{L_{\lambda \max }}=5 \frac{\partial T}{T}$ を得ることが出来る。

又 $p$ はと反比例の関係にあるから， $\lambda_{\max }$ を含むあ らゆる波長域に执いてpは $5 \lambda_{\max } / \lambda$ の関係を得る。ゆ 光酒, (13)式は,

$$
\frac{\partial L_{\lambda}}{L_{\lambda}}=5 \cdot \frac{\lambda_{\max }}{\lambda} \frac{\partial T}{T}
$$

と置き換光ることが出来る。この式でpは最大放射輝 度を放出する $\lambda_{\max }$ を任意の $\lambda$ で割ったものを 5 倍し たものに等しいことを示している。

(15)式の応用例として, $T=290 \mathrm{~K}$ の時 $\left(\lambda_{\max } \doteqdot 10 \mu \mathrm{m}\right)$

$$
\begin{array}{ll}
\lambda=10 \mu \mathrm{m} \text { では }, & p=5 \\
\lambda=5 \mu \mathrm{m} \text { では }, & p=5 \cdot \frac{\lambda_{\max }}{\lambda} \doteqdot 5 \frac{10}{5}=10
\end{array}
$$


$\lambda=3.3 \mu \mathrm{m}$ では, $\quad p=5 \cdot \frac{\lambda \max }{\lambda} \doteqdot 5 \frac{10}{3.3}=15$

となる。

一方，図 3 で温度変化によるそれぞれの放射輝度変 化を見たとき，例えば $305 \mathrm{~K} か ら ~ 5 \mathrm{~K}$ (温度1.64\%の增 減）の变化汶し， $11 \mu \mathrm{m}$ 飞打ける放射輝度変化は $7.4 \% ， 3.3 \mu \mathrm{m}$ 飞おいては26\%の変化を知った。すな わち,

$11 \mu \mathrm{m}$ の時 $\frac{\partial L_{\lambda}}{L_{\lambda}}=7.4 \%, \frac{\partial T}{T}=1.64 \%$

これを(12)式又は(14)式に代入してみると，

$7.4=p \times 1.64 \quad \therefore p=4.5 \quad$ となる。 同様にして， $5 \mu \mathrm{m}$ の時， $16.7=p \times 1.64$

$$
\therefore p=10.2
$$

3. $3 \mu \mathrm{m}$ の時, $26=p \times 1.64 \therefore p=15.8$ となる。 これらの数值をグラフから読み取った䛊差を考慮に入 れて, 前回に得た数值と比較してみると, ほぼ一致す ることがわかる。そして，温度変化に対する放射輝度 の変化を見る場合，簡単な(12)式が十分に用いられる ことがわかった。特に微量変化に対して有効で，大き な变化に対しては図 3 を用いるのがよいと思われる。 そして，ここに沶いても，物体の微少な温度変化に対 して, 中間赤外の方が大きな放射輝度変化を示すこと がわかった。

\section{$p_{\mathrm{MIR}}>p_{\mathrm{FIR}}$}

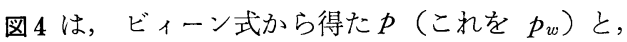
プランクスの法則から得た $p$ (これを $\left.p_{p}\right)$ との関倸を しるした。 $p_{w}$ は(14)式より, $p_{w}=\left(T \partial L_{\lambda}\right) /\left(L_{\lambda} \partial T\right)=$ $c_{2} \lambda^{-1} T^{-1}=5 \lambda_{\max } / \lambda \cdots \cdots$..(16) 又 $\lambda_{\max }$ を含むすべての 領域に対して有効な $p_{p}$ は(11)式から次のように導び き出される。

$$
\begin{gathered}
\frac{\partial L_{\lambda}}{\partial T}=L_{\lambda} c_{2} \lambda^{-1} T^{-2}\left[1-\exp \left(-c_{2} \lambda^{-1} T^{-1}\right)\right]^{-1} \\
\therefore \quad p_{p}=\frac{\partial L_{\lambda}}{L_{\lambda}} \cdot \frac{T}{\partial T}=c_{2} \lambda^{-1} T^{-1}\left[1-\exp \left(-c_{2} \lambda^{-1}\right.\right. \\
\left.\left.T^{-1}\right)\right]^{-1} \quad \cdots \cdots .(17)
\end{gathered}
$$

このことから，波長が長くなるにつれて， $p_{w}$ の $p_{p}$ に 対する誤差が大きくなり， $\lambda>2 \lambda_{\text {max }}$ においては， $p_{w}$ は意味をもたなくなる3。

\section{5. ステファン・ボルツマンの法則}

一般によく知られている全波長輝度の積分価が $T^{4}$ 飞比例しているといらステファン・ボルッマンの法則 (The Stefan-Boltzmann law) をとりあげ，そのプ ランクス近似式としての役割を考えてみたい（ここで は，全波長領域の黑体放射散乱を考光ているため単位 面積 $\left(1 \mathrm{~m}^{2}\right)$ 当りの放射量を単位とする)。ステファ
ン・ボルッマンの法則は次のように表わされる。

$$
M=5.67 \times 10^{-8} \times T^{4}\left[\mathrm{Wm}^{-2}\right]
$$

すなわち，この式は各スペクトルごとの放射量 $\left(M_{\lambda}=\right.$ $\left.\pi \times L_{\lambda}\right)$ を表わすプランクスの 法則を積分することに より得られる。

$$
\begin{aligned}
& M=\int_{0}^{\infty} M_{\lambda} d \lambda \quad\left(M_{\lambda}=c_{1} \lambda^{-5}\left[\exp \left(c_{2} \lambda^{-1} T^{-1}\right)-1\right]^{-1}\right. \\
& \ldots . . . . . . . .70 \text { フォクスの法則 })
\end{aligned}
$$

逆に(18)式をTで微分してみると，

$$
\begin{aligned}
\frac{\partial M}{\partial T} & =4 \alpha T^{3} \quad\left(\alpha=5.67 \times 10^{-8}\right) \\
& =4 \alpha T^{4} \cdot T^{-1} \\
& =4 M T^{-1} \\
\frac{\partial M}{M} & =4 \frac{\partial T}{T} \quad \therefore \quad p=4\left(p_{a v}\right) \text { となり },
\end{aligned}
$$

ステファン・ボルッマンの法則から放射量（全スペク トル領域）の比例数*4は $p=4\left(p_{a v}\right)$ であることがわか る。これは, プランクスの法則から得られた(17)式を 積分して，その平均をとってみた時と同じことを意味 している。

$$
\begin{aligned}
p_{a v}= & R^{-1} \int_{0}^{\infty} p_{p} d \lambda=R^{-1} \int_{0}^{\infty} c_{2} \lambda^{-1} T^{-1}[1-\exp \\
& \left.\left(-c \lambda^{-1} T^{-1}\right)^{-1}\right] d \lambda=4 \quad \cdots \cdots(19)
\end{aligned}
$$

一方, 図4の $p_{p}$ カーブの平均值化いても 4 を示す ことはいらまでもない。

プランクスの法則を正しいとした場合，以上のこと から放射に関するステファン・ボルッマンの法則はあ らゆるスペクトル領域の放射量を測定出来たときと有 効となることがわかった。すなわち，エアーボーンか らのリモート・センシングにおいては，必ず大気の放 射吸収領域にぶつかるため, このような測定は不可能 である。ゆ无に $p_{a v}=4$ の関係（ステファン・ボルッ マンの法則）は本来応用してはならないものである。 しかし, ある温度でスペクトル放射輝度が $T$ の 4 乗 $\left(p_{a v}=4\right)$ 飞比例し, ステファン・ボルッマンの法則 が成り立つスペクトル領域がある。それは， $12.5 \mu \mathrm{m}$ の波長領域に反応する検知機で， $T=290 \mathrm{~K}$ の物体の 放射輝度を測定する場合である。すなわちpは

$$
\begin{aligned}
& p=c_{2} / \lambda T=14,388 /(12.5 \times 290) \doteqdot 4 \text { となり, } \\
& \Delta L_{\lambda} \%=4 \times \Delta T \% \\
& \therefore \quad L_{\lambda}=\sigma_{1} T^{4}
\end{aligned}
$$

を得, スエファン・ボルッマンの法則に一致するわけ である。又ある目的物の周辺へ放出する熱量を計算す る場合にもステファン・ボルッマンの法則は成り立 つ。例壳ば，273Kの物体が外部に放出する熱量は $M$ $=5.67 \times 10^{-8} \times(273)^{4}=315 \mathrm{~W}^{-2}$ だけ放出することに なる(放射輝度に変えると $L=100 \mathrm{Wm}^{-2} \mathrm{sr}^{-1}$ となる)。 又 $305 \mathrm{~K}$ の人の裸体を考光た場合，(17)式から $1.25 \mathrm{~m}^{2}$ 


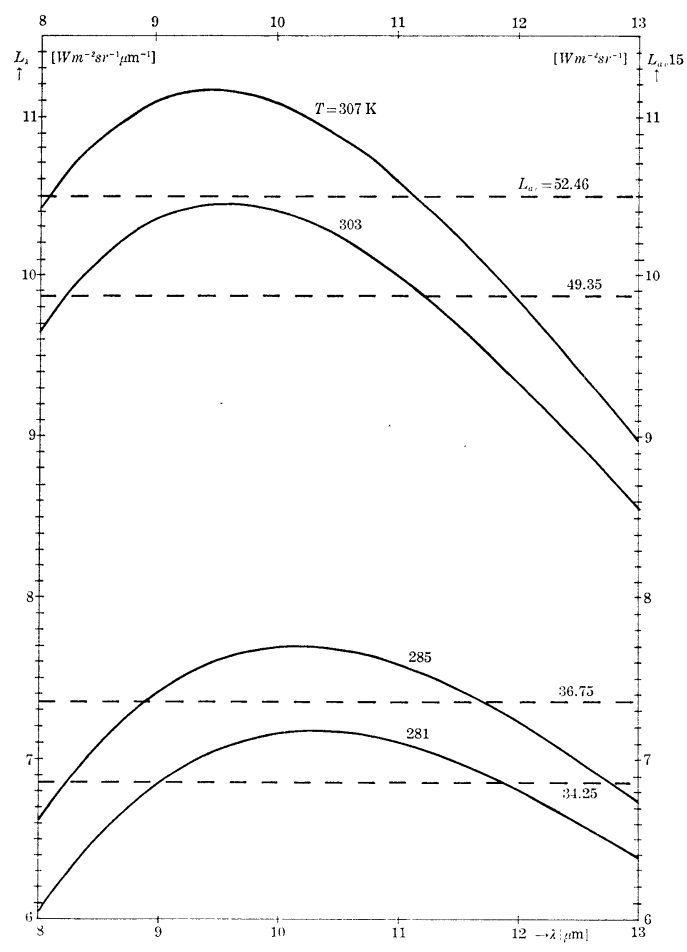

図 5 遠赤外を対象としたプランクス法則黒体放射 カーブ

体温に当る $303 \mathrm{~K}$ から $307 \mathrm{~K}$ な゙の温度と, 海面温度に当 る $281 \mathrm{~K} か ら 285 \mathrm{~K}$ ，とれぞれ $4{ }^{\circ} \mathrm{C}$ 変化間で示した。 それぞれのカーブにひかれた直線は $8 \sim 13 \mu \mathrm{m}$ までの放 射輝度の平均值（(19) 式の $p_{a v}$ から計算）

で周辺に 600W 放出することになる。そして，この 人の周辺大気が $294 \mathrm{~K}$ と人体より低温の場合, その人 は大気から $500 W$ のを吸収する。すなわち，その人 は $100 \mathrm{~W}$ のネルギー減少を余儀なくされたことにな る。

医学界においては，熱写真を用いた体温分布を見る のによくこのステファン・ボルッマンの法則が用いら れる。がしかし医学で用いられる検知機は普通 $8 \sim 13$ $\mu \mathrm{m}$ の遠赤外領域の放射を検知するものである。そこ で，体温を $305 \mathrm{~K}$ とした場合，この条件のもとでビィ ーン式から得られたスペクトル放射輝度の比例式(13) 式の積分函数 $\int p_{\omega}$ に代入してみると，

$$
\begin{aligned}
\bar{p}_{a v}=R^{-1} \int_{\lambda_{1}}^{\lambda_{2}} p_{w} & =\frac{1}{\lambda_{2}-\lambda_{1}} \int_{\lambda_{1}}^{\lambda_{2}} c_{2} \lambda^{-1} T^{-1} d \lambda \\
& =\frac{14388}{\lambda_{2}-\lambda_{1}} \cdot \frac{1}{T} \int_{\lambda_{1}}^{\lambda_{2}} \lambda^{-1} d \lambda \\
& =\frac{14388}{\lambda_{2}-\lambda_{1}} \cdot \frac{1}{T} \ln \frac{\lambda_{2}}{\lambda_{1}}
\end{aligned}
$$

$$
\therefore \quad \bar{p}_{a v}=\frac{1}{13-8} \int_{8}^{13} p_{w}=\frac{14388}{5 \times 305} \ln 13 / 8=4.58
$$

を得る。このことから, 上記の条件で, 放射輝度の変
化は4.58乗に比例することがわかった。又図 4 からも この条件を満足する $\lambda T=2440 \sim 4015$ 範囲として $p_{p}=$ 4.5 となる

さらにもら少し精密な $p$ 值を得ようとするならば, 次のよらな方法を取らなくてはならない。罒 5 は 8〜 $13 \mu \mathrm{m}$ の領域で人間の体温限界点と思われる $T_{1}=303$ $\mathrm{K}$ から $T_{2}=307 \mathrm{~K}$ の黑体放射カーブを描き，それぞれ の平均値を点線 $\left(\bar{L}_{a v}\right)$ で示した。そして(17)式から 得られる,

$$
\begin{aligned}
\bar{p}_{a v}= & \left(T_{2}+T_{1}\right)\left(T_{2}-T_{1}\right)^{-1}+\left(\bar{L}_{a v\left(T_{2}\right)}-\bar{L}_{a v\left(T_{1}\right)}\right) \\
& \left(\bar{L}_{a v\left(T_{2}\right)}+\bar{L}_{a v\left(T_{1}\right)}\right)^{-1} \quad \cdots \cdots(21)
\end{aligned}
$$

に条件となる $T_{1}=303, T_{2}=307, \quad \bar{L}_{a v\left(T_{1}\right)}=49.35$ $\bar{L}_{a v\left(T_{2}\right)}=52.46$ を代入すると， $T_{1}$ から $T_{2}$ への温度変 化に対する比例数 $\bar{p}_{a v}=4.63$ を得ることが出来る。又 $T=305 \mathrm{~K}$ 前後の微少な変化を考光た場合, 同様に(17) 式 $p_{p}=c_{2} \lambda^{-1} T^{-1}\left\{1-\exp \left(-c_{2} \lambda^{-1} T^{-1}\right)\right\}^{-1} を 8 \sim 13 \mu \mathrm{m}$ 内で積分し，その平均を出してみると，

$$
\begin{aligned}
\bar{p}_{a v}= & \frac{1}{\lambda_{2}-\lambda_{1}} \cdot \frac{14,388}{T} \int_{\lambda_{1}}^{\lambda_{2}} \lambda^{-1}\left\{1-\exp \left(-14388 \lambda^{-1}\right.\right. \\
& \left.\left.T^{-1}\right)\right\}^{-1} d \lambda \quad \cdots \cdots(22)
\end{aligned}
$$

より $\bar{p}_{a v}=4.64$ を得ることが出来る。

このことより $8 \sim 13 \mu \mathrm{m}$ の領域を検知する装置を用 いた体温測定には，ステファン・ボルツマンの法則を 次のように修正して用いるのが正しい。

$L_{\mathrm{FIR}} \div T^{4.64}$ (人間の皮膚 $305 \mathrm{~K}$ 前後を対象とした 場合) ...(23)

もし，エアー・ボーンからのリモート・センシング に，この公式を用いる場合は，次の事を考慮せね䛱な らない。

(i) $8 \sim 13 \mu \mathrm{m}$ の空に反応する赤外線走査装置を用 いること。

(ii) 大気が $8 \sim 13 \mu \mathrm{m}$ の範囲で, 均一に放射量を透 過する状態にあること。

(iii) 検知機が $8 \sim 13 \mu \mathrm{m}$ の範囲で均一に放射輝度を 検知出来ること。

(iv) 対象とする物体が $8 \sim 13 \mu \mathrm{m}$ の範囲内で均一の 放射率をもっていること。

(v)体温のように，305K 前後の物体を対象とする こと。

(vi) 対象とする物体の温度範囲が非常に狭いこと。 地球表面のリモート・センシングでは，上記に示し た制限を満足するもので，非常に狭い範囲の絶対的海 面温度測定によく用いられる。

(21)(22)式を用いて，282Kから293K 前後を対象と する海面温度に関して見てみるると，

$$
\begin{array}{ll}
L_{\mathrm{FIR}} \div T^{4.99} & \text { (282Kの時) } \\
L_{\mathrm{FIR}} \div T^{4.82} & \text { (293Kの時) }
\end{array}
$$


を得ることが出来る。しかし，リモート・センシング による調查の場合, FIR 内のオン゙ン $\left(\mathrm{O}_{3}\right)$ による吸収 が，条件(ii)に矛盾する。したがって，この式を用いる 場合，数多くの実験を積又重亦，大気の状況を十分に 認識した上でなければならない。

\section{6. あとがき}

最初に述べたように，このレポートは 1974 年代, ITC 物理部で研究されたことを筆者 (Hempenius) がまとめたもので，これを訳者が ITC 在学中，抄訳 したものである。日本では，最近，遠赤外を用いた thermography の調查が，数多く実施されるようにな ってきた。我々は，このレポートが，これらに役立て れば幸いです。尚，このレポート（英文）は ITC ジ ヤーナル7に登載された。

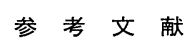

1) Kaminski, H., 1973: Infrarot-Satellitenaufnahmen in den Geowissenschaften. Zum Vergleich der IR-Bereiche von 3-4 $\mu \mathrm{m}$ und 10-12 $\mu \mathrm{m}$. Bildmessung und Luftbildwesen 1973 No. 1, 21-29

2) Vincent, R.K., 1972: Experimental Methods for Geological Remote Sensing. 4th Annual Earth Resources Program Review NASA MSC-05937, Section 33,12

Vincent, R.K., and F. Thomson, 1972: Recognition of Exposed Quartz Sand and Sandstone by Two-Channel Infrared Imagery. J. Geophysical Res., Vol. 77, No. 14, 2473-2477

3) Hudson, R.D., 1969: Infrared System Engineering, John Wiley \& Sons, New York, 642, Chapter 2, Infrared Radiation 20-63

4) Levi, L., 1974: Blackbody Temperature for Threshold Visibility, Appl. Optics, 13(2), 221

5) Meyer-Arendt, J.R., 1955: Radiometry and Photometry: Unit's and Conversion Factors. Appl. Optics, 7(10), 20814

6）広沢春任：昭和49年10月：リモート・センシングにお ける電磁波に関する基礎知識。日米合同セミナー,リ モートセンシングの原理と応用

7) S.A. Hempenius, 1975: Infrared Thermography at the ITC; Part 1: the Radiation Laws. The ITC Journal 1975-1 1 52

扮知 らせ

\section{国際写真測量学会（ISP）第13回総会}

ISP の第13回総会が，今年の 7 月 11 日から 23 日の 間，フィンランドのヘルシンキで開催されます。

スケジュールは，次のと扔りです。

参加費は申込時期によって变わるようになって打 り，次のよう飞決められて和ります。

\begin{tabular}{|c|c|c|c|}
\hline 期 間 & 2 月 29 日以前 & $\begin{array}{r}3 \text { 月 } 1 \text { 昌 } \widetilde{1} \\
430 \text { 日 } \\
\end{array}$ & 5 月 1 日以降 \\
\hline 一般会員 & 230 Sfr. & 280 Sfr. & 230 Sfr. \\
\hline 学 生 & $115 \prime \prime$ & $140 \quad \prime \prime$ & $165 \prime \prime$ \\
\hline
\end{tabular}

申込用紙は学会事務局にあります。また，参加者の 団体旅行扱いも計画されて招りますが，詳細は学会事 務局に扮尋亦下さい。
JGP KONGRESS HELSINKI 1976

$z$ e i t p i a n

BI ...BVII = Geschäf tsversarmlung von

I...vil $=$ Technische Versarmlung von

\begin{tabular}{|c|c|c|c|c|c|c|c|c|c|c|c|c|c|}
\hline $\begin{array}{l}\text { un } \\
\text { ze } \\
\text { Catum und } \\
\text { Auditorium. }\end{array}$ & & $\begin{array}{l}\circ \\
\vdots \\
\vdots\end{array}$ & $=$ & 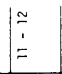 & $\mid \begin{array}{c}m \\
\check{2} \\
\end{array}$ & $\stackrel{ \pm}{i}$ & $\stackrel{2}{\vdots}$ & 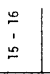 & $\dddot{\check{L}}$ & $\stackrel{\infty}{\vdots}$ & $\begin{array}{l}\stackrel{2}{1} \\
\stackrel{\infty}{\longleftarrow}\end{array}$ & $\stackrel{2}{2}$ & $\begin{array}{c}1 \\
1 \\
1\end{array}$ \\
\hline \multicolumn{2}{|l|}{ So $07-11$} & \multicolumn{12}{|c|}{ 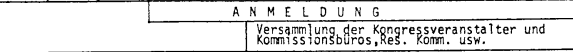 } \\
\hline \multirow{2}{*}{$\mu_{n} \quad 07-12$} & \multirow{2}{*}{$\begin{array}{l}\mathrm{A} \\
\mathrm{B}\end{array}$} & \multirow{2}{*}{\multicolumn{3}{|c|}{ 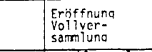 }} & & & BI & BVII & $\mathrm{BV}$ & & & & \\
\hline & & & & & & & BVI & BII & BIV & & & & \\
\hline \multirow{2}{*}{$\begin{array}{lll}01 & 07-13\end{array}$} & \multirow{2}{*}{ A } & \multirow{2}{*}{\multicolumn{3}{|c|}{\begin{tabular}{|l|l} 
Eröffnung & $\begin{array}{l}\text { General- } \\
\text { versaanmi. } \\
\text { der Ausstel }\end{array}$ ungen \\
\end{tabular}}} & & & II1 & & III & & & & \\
\hline & & & & & & & II & & VI & & & & \\
\hline \multirow{2}{*}{$\mu_{1} \quad 07-14$} & $A$ & 111 & & $v$ & & & III & & VII & & & & \\
\hline & $B$ & II & & IV & & & 1 & & $V_{1}$ & & & & \\
\hline \multirow[b]{2}{*}{$\begin{array}{llll}0 & 07-15\end{array}$} & A & 1 & & I & & & $\begin{array}{l}\text { General- } \\
\text { versanm }\end{array}$ & & II & & & & \\
\hline & B & IV & & IV & & & $r$ & & v & & & & \\
\hline \multirow{2}{*}{ Fr 07-16 } & A & VII & & VII & & & I & & I & & & & \\
\hline & $B$ & II & & IV & & & $y$ & & VI & & & & \\
\hline Sa $07-17$ & & \multicolumn{12}{|c|}{ TOUREN, AUSSTELLUNG } \\
\hline So $07-18$ & & \multicolumn{12}{|c|}{ TOUREN } \\
\hline \multirow[b]{2}{*}{ in $07-19$} & A & $\mathrm{VHI}$ & & VII & & & $I$ & & III & & & & \\
\hline & B & v & & $v$ & & & It & & II & & & & \\
\hline \multirow{2}{*}{ Di $07-20$} & A & VII & & III & & & \begin{tabular}{|l|} 
Genera1- \\
versarmm
\end{tabular} & & IIt & & & & \\
\hline & B & $v$ & & VI & & & $v$ & & IV & & & & \\
\hline Mi $07-21$ & & \multicolumn{9}{|c|}{ 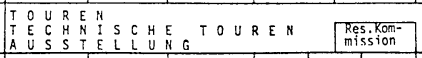 } & & & \\
\hline \multirow{2}{*}{$\begin{array}{llll}D 0 & 07-22\end{array}$} & A & $v$ & & 8III & & & BI & BVII & BV & & & & \\
\hline & B & IV & & vi & & & $8 \mathrm{VI}$ & BII & BIV & & & & \\
\hline \multirow{2}{*}{ Fr $07-23$} & A & $I$ & & III & & & VII & & VII & & \multirow{2}{*}{\multicolumn{3}{|c|}{$\begin{array}{l}\text { Yollversamilung } \\
\text { Abschlussfeier }\end{array}$}} \\
\hline & E & II & & v & & & $v$ & & IV & & & & \\
\hline
\end{tabular}

SCHLIESSEN DER AUSSTELLUUNG 